\title{
Female genital mutilation and cutting: a systematic literature review of health professionals' knowledge, attitudes and clinical practice
}

Yvonne Zurynski ${ }^{1,2^{*}}$, Premala Sureshkumar ${ }^{1,2}$, Amy Phu $^{1,2}$ and Elizabeth Elliott ${ }^{1,2,3}$

\begin{abstract}
Background: The World Health Organisation (WHO) estimates that 100-140 million girls and women have undergone female genital mutilation or cutting (FGM/C). FGM/C is an ancient cultural practice prevalent in 26 countries in Africa, the Middle East and Asia. With increased immigration, health professionals in high income countries including UK, Europe, North America and Australia care for women and girls with FGM/C. FGM/C is relevant to paediatric practice as it is usually performed in children, however, health professionals' knowledge, clinical practice, and attitudes to FGM/C have not been systematically described. We aimed to conduct a systematic review of the literature to address this gap.

Methods: The review was conducted according to guidelines of the Preferred Reporting Items for Systematic Reviews and Meta-Analyses (PRISMA) statement and registered with the PROSPERO International Prospective Register of Systematic Reviews (CRD42015015540, http://www.crd.york.ac.uk/PROSPERO/). Articles published in English 2000-2014 which used quantitative methods were reviewed.

Results: Of 159 unique articles, 18 met inclusion criteria. The methodological quality was poor - six studies met seven of the eight quality criteria. Study participants included mainly obstetricians, gynaecologists and midwives (15 studies). We found no papers that studied paediatricians specifically, but two papers reported on subgroups of paediatricians within a mixed sample of health professionals. The 18 articles covered 13 different countries: eight from Africa and 10 from high income countries. Most health professionals were aware of the practice of FGM/C, but few correctly identified the four FGM/C categories defined by WHO. Knowledge about FGM/C legislation varied: 25 $\%$ of professionals in a Sudanese study, $46 \%$ of Belgian labour ward staff and $94 \%$ of health professionals from the UK knew that FGM/C was illegal in their country. Health professionals from high income countries had cared for women or girls with FGM/C. The need to report children with $F G M / C$, or at risk of $F G M / C$, to child protection authorities was mentioned by only two studies.
\end{abstract}

Conclusion: Further research is needed to determine health professionals' attitudes, knowledge and practice to support the development of educational materials and policy to raise awareness and to prevent this harmful practice.

Keywords: Female genital mutilation or cutting, Health professionals, Knowledge, Attitudes, Practice

\footnotetext{
* Correspondence: yvonne.zurynski@sydney.edu.au

'Australian Paediatric Surveillance Unit, The Children's Hospital at Westmead,

Sydney, Australia

${ }^{2}$ Discipline of Paediatrics and Child Health, Sydney Medical School, The

University of Sydney, Sydney, Australia

Full list of author information is available at the end of the article
}

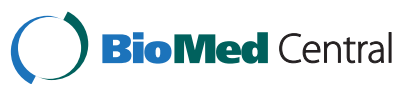

(c) 2015 Zurynski et al. Open Access This article is distributed under the terms of the Creative Commons Attribution 4.0 International License (http://creativecommons.org/licenses/by/4.0/), which permits unrestricted use, distribution, and reproduction in any medium, provided you give appropriate credit to the original author(s) and the source, provide a link to the Creative Commons license, and indicate if changes were made. The Creative Commons Public Domain Dedication waiver (http://creativecommons.org/publicdomain/zero/1.0/) applies to the data made available in this article, unless otherwise stated. 


\section{Background}

The World Health Organisation (WHO) estimates that between 100-140 million girls and women have undergone female genital mutilation or cutting (FGM/C) [1]. FGM/C is usually performed in children aged between 1 month and 15 years, and is therefore relevant to paediatric practice [2]. There are different types of FGM/C procedures ranging from "nicking" or "pricking" the prepuce, to complete removal of the clitoris or infibulation, when the vaginal opening is narrowed by cutting and repositioning the inner or outer, labia, with or without removal of the clitoris [1,3]. FGM/C is an ancient cultural practice, predating both the Bible and the Koran and has no basis in religion [4]. FGM/C is currently customary in over 26 countries in Africa, the Middle East and Asia, with a prevalence of $70 \%$ or more reported in 11 African countries including Somalia, Egypt, Sierra Leone, Sudan, Mali, Eritrea, and Ethiopia [2]. There are no medical or health indications for FGM/C. FGM/C is harmful and immediate complications include bleeding, pain, infections and significant psychological trauma $[1,2,5,6]$. Long term complications include recurrent urinary infections, birthing difficulties including need for emergency caesarean section, third-degree vaginal tears, and ongoing psychological and sexual problems [1, 2, 4-8].

All forms of FGM/C whether performed by medical practitioners or other "cultural practitioners" are illegal in at least 20 countries in Africa including Kenya, Nigeria and Egypt [9], and in high income countries such as Australia, New Zealand, United Kingdom, Republic of Ireland, Canada, many European Countries, and 15 of the 52 States of the USA have law where parents/guardians and circumcisers are subject to prosecution [4-6, 10-12]. Furthermore, it is illegal to organise for FGM/C procedures to be performed overseas in children resident in many of these high income countries [5-7, 10, 12]. FGM/ $\mathrm{C}$ is a child protection issue and in many countries, mandatory reporting to authorities is required by health professionals who identify children who have undergone FGM/C or who are believed to be at risk of FGM/C [4-7, 10-12]. FGM/C violates the UN Charter of Human Rights, the UN Charter of Women's Rights, the Charter of the Rights of the Child, and the Charter of Rights of the African Child [13-16].

Medicalization of FGM/C refers to the procedure being performed in a medical setting, often by a doctor $[17,18]$. A recent study from the UK reported that of 27 girls who had FGM/C, it was known to have been performed by a doctor in a medical setting in $71 \%$ [19]. Medicalization is often supported by those who practice FGM/C because they believe it offers "harm reduction" by preventing immediate medical complications $[17,18]$. However, the involvement of healthcare providers in FGM/C in any setting has been condemned by the WHO because it does not prevent long-term medical or psychological complications and legitimises continuation of FGM/C in some communities $[1,3]$.

Many women with $\mathrm{FGM} / \mathrm{C}$ and girls at risk of FGM/C are now living in the UK, Europe, North America, Australia and New Zealand due to the increasing immigration from countries where $\mathrm{FGM} / \mathrm{C}$ is prevalent $[4-7,10-12]$. The prevalence of FGM/C in girls and women living in these countries is unknown, because procedures tend to be organised by families in private, often outside the mainstream health system, and information about $\mathrm{FGM} / \mathrm{C}$ is not routinely collected or coded in medical records. Furthermore, girls may be taken for FGM/C to the family's country of origin [5]. Thus, FGM/C may only become apparent to health professionals when girls or young women present with complications, or when women need obstetric and gynaecological care $[5,7,20]$.

As the immigrant communities in high income countries become larger and increasingly multicultural and ethnically diverse, health professionals are more likely to see women and girls with FGM/C or at risk of $\mathrm{FGM} / \mathrm{C}$, in their clinical practice. In this systematic review of the literature we aimed to identify, describe and analyse publications reporting the knowledge, attitudes and clinical practices related to FGM/C among health professionals internationally. We aimed to answer the following questions:

1. Do health professionals have experience of FGM/C in their clinical practice?

2. Do health professionals have adequate knowledge about FGM/C categories, complications, and high risk groups and do they have access to education and training opportunities?

3. Do health professionals have adequate knowledge about laws relating to $\mathrm{FGM} / \mathrm{C}$ ?

4. What are the attitudes and beliefs of health professionals towards the practice of $\mathrm{FGM} / \mathrm{C}$ ?

\section{Methods}

Systematic review of the literature using the terms "female genital mutilation", "female genital cutting" or "female circumcision" combined with MESH terms: "Paediatrics", "Child Health" and keywords: "paediatrician", "practice guidelines," "attitudes" "knowledge" and "education" was conducted. Databases including MEDLINE, CINHAL and SCOPUS were searched applying limits: year of publication 2000-2014; human; English language.

The review was conducted according to guidelines of the Preferred Reporting Items for Systematic Reviews and Meta-Analyses (PRISMA) statement and registered with the PROSPERO International Prospective 


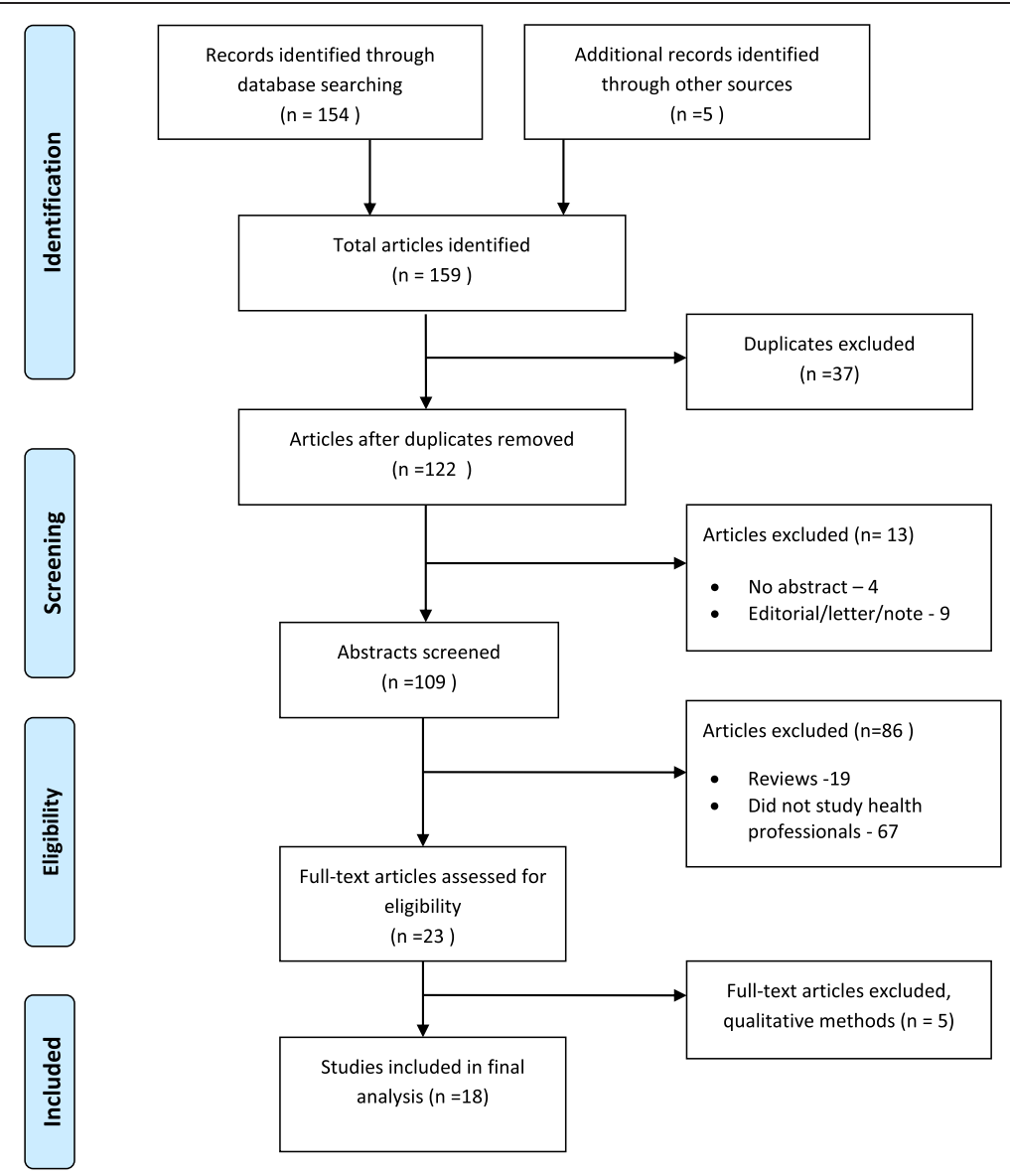

Fig. 1 Identification and selection of studies for review

Registerof Systematic Reviews (CRD42015015540, http://www.crd.york.ac.uk/PROSPERO/).

The titles and abstracts of all articles identified through the literature search were scanned for relevance. Documents were selected for full review if they specifically mentioned FGM/C, and reported primary data on health professionals' knowledge attitudes and clinical practice related to $\mathrm{FGM} / \mathrm{C}$.

\section{Definitions}

WHO definitions of the 4 types of FGM/C:

1. Clitoridectomy: partial or total removal of the clitoris (a small, sensitive and erectile part of the female genitals) and, in very rare cases, only the prepuce (the fold of skin surrounding the clitoris).

2. Excision: partial or total removal of the clitoris and the labia minora, with or without excision of the labia majora (the labia are "the lips" that surround the vagina).
3. Infibulation: narrowing of the vaginal opening through the creation of a covering seal. The seal is formed by cutting and repositioning the inner, or outer, labia, with or without removal of the clitoris.

4. Other: all other harmful procedures to the female genitalia for non-medical purposes, e.g. pricking, piercing, incising, scraping and cauterizing the genital area.

Other definitions:

5. De-infibulation: is the surgical procedure to open up the closed vagina of FGM type 3 and is often performed on the wedding night, and prior to childbirth.

6. Reinfibulation: The re-stitching of FGM type III to reclose the vagina after childbirth.

\section{Inclusion criteria}

\section{Design}

Human observational studies, including cross sectional, cohort or population-based studies that used quantitative methodology. 
Table 1 Characteristics of studies included in the review

\begin{tabular}{|c|c|c|c|c|c|c|c|c|}
\hline \multirow[t]{2}{*}{ Reference } & \multirow[t]{2}{*}{ Country } & \multirow[t]{2}{*}{ Study design and method } & \multicolumn{3}{|c|}{ Domains assessed } & \multirow[t]{2}{*}{ Sample } & \multirow[t]{2}{*}{ N } & \multirow{2}{*}{$\begin{array}{l}\text { Response } \\
\text { rate }\end{array}$} \\
\hline & & & Attitudes & Knowledge & $\overline{\text { Practice }}$ & & & \\
\hline \multicolumn{9}{|l|}{ Publications from African Countries } \\
\hline Ashimi et al. 2014 [21] & Nigeria & $\begin{array}{l}\text { Cross-sectional; } \\
\text { self- administered } \\
\text { survey }\end{array}$ & Yes & Yes & No & Nurses & 350 & $84 \%$ \\
\hline Kaplan et al. 2013 [22] & Gambia & $\begin{array}{l}\text { Cross-sectional; } \\
\text { survey administered } \\
\text { face to face }\end{array}$ & Yes & Yes & Yes & $\begin{array}{l}\text { Nurses, community } \\
\text { nurses and midwives }\end{array}$ & 468 & NR \\
\hline Ali et al. 2012 [23] & Sudan & $\begin{array}{l}\text { Survey administered } \\
\text { via face to face } \\
\text { interview }\end{array}$ & Yes & Yes & Yes & $\begin{array}{l}\text { Midwives ( } 63 \% \text { of } \\
\text { midwives were illiterate) }\end{array}$ & 157 & $N R$ \\
\hline Dike et al. 2012 [24] & Nigeria & $\begin{array}{l}\text { Cross-sectional } \\
\text { survey }\end{array}$ & Yes & Yes & No & $\begin{array}{l}\text { Student nurses and } \\
\text { midwives }\end{array}$ & 269 & $95.7 \%$ \\
\hline Rasheed et al. 2011 [25] & Egypt & $\begin{array}{l}\text { Cross sectional; } \\
\text { self- administered } \\
\text { survey }\end{array}$ & Yes & No & Yes & $\begin{array}{l}\text { aNurses; junior } \\
\text { and senior physicians }\end{array}$ & & \\
\hline Refaat 2009 [26] & Egypt & $\begin{array}{l}\text { Cross-sectional } \\
\text { Survey }\end{array}$ & Yes & Yes & Yes & aphysicians & 193 & $68 \%$ \\
\hline Mostafa et al. 2006 [27] & Egypt & $\begin{array}{l}\text { Random sample; } \\
\text { Survey }\end{array}$ & Yes & Yes & No & $\begin{array}{l}5^{\text {th }} \text { year medical } \\
\text { students }\end{array}$ & 330 & $90.3 \%$ \\
\hline Onuh et al. 2006 [28] & Nigeria & $\begin{array}{l}\text { Cross-sectional; } \\
\text { Survey }\end{array}$ & Yes & Yes & Yes & $\begin{array}{l}\text { Nurses practising in } \\
\text { a hospital }\end{array}$ & 182 & $94.3 \%$ \\
\hline \multicolumn{9}{|c|}{ Publications from "Western Countries" } \\
\hline Caroppo et al. 2014 [29] & Italy & $\begin{array}{l}\text { Purposive sample; } \\
\text { Self-administered } \\
\text { survey }\end{array}$ & No & Yes & Yes & $\begin{array}{l}\text { Physicians, social } \\
\text { workers, psychologists, } \\
\text { "health assistants" } \\
\text { working in an asylum } \\
\text { seeker centre }\end{array}$ & 41 & $100 \%$ \\
\hline Purchase et al. 2013 [30] & UK & $\begin{array}{l}\text { Cross-sectional; } \\
\text { survey }\end{array}$ & No & Yes & No & $\begin{array}{l}\text { Obstetricians and } \\
\text { Gynaecologists }\end{array}$ & 607 & $20.1 \%$ \\
\hline Relph et al. 2013 [31] & UK & $\begin{array}{l}\text { Cross-sectional; } \\
\text { Survey }\end{array}$ & Yes & Yes & No & $\begin{array}{l}\text { Health care } \\
\text { professionals }\end{array}$ & 79 & $92.9 \%$ \\
\hline \multirow[t]{2}{*}{ Moeed et al. 2012 [20] } & \multirow[t]{2}{*}{$\begin{array}{l}\text { Australia } \\
\text { and New } \\
\text { Zealand }\end{array}$} & \multirow[t]{2}{*}{$\begin{array}{l}\text { Cross- sectional; } \\
\text { Survey }\end{array}$} & \multirow[t]{2}{*}{ No } & \multirow[t]{2}{*}{ Yes } & \multirow[t]{2}{*}{ Yes } & $\begin{array}{l}\text { Obstetricians and } \\
\text { Gynaecologists } \\
\text { and trainees }\end{array}$ & 564 & $18.5 \%$ \\
\hline & & & & & & FGM/C workers & 34 & $91.9 \%$ \\
\hline Hess et al. 2010 [32] & USA & $\begin{array}{l}\text { Randomised } \\
\text { Survey }\end{array}$ & Yes & Yes & Yes & Nurse-midwives & 243 & $40.3 \%$ \\
\hline \multirow[t]{2}{*}{ Kaplan-Marcusan et al. 2009 [33] } & \multirow[t]{2}{*}{ Spain } & \multirow{2}{*}{$\begin{array}{l}\text { Cross-sectional; } \\
\text { Survey at two } \\
\text { time points } \\
\text { (2001 and 2004) }\end{array}$} & \multirow[t]{2}{*}{ Yes } & \multirow[t]{2}{*}{ Yes } & \multirow[t]{2}{*}{ Yes } & \multirow[t]{2}{*}{$\begin{array}{l}\text { bPrimary health } \\
\text { care professionals }\end{array}$} & $\begin{array}{l}280 \\
(2001)\end{array}$ & $\begin{array}{l}80 \% \\
(2001)\end{array}$ \\
\hline & & & & & & & $\begin{array}{l}296 \\
(2004)\end{array}$ & $\begin{array}{l}62 \% \\
(2004)\end{array}$ \\
\hline Leye 2008 [34] & Belgium & $\begin{array}{l}\text { Cross-sectional; } \\
\text { Survey }\end{array}$ & Yes & Yes & Yes & $\begin{array}{l}\text { Gynaecologists and } \\
\text { trainees }\end{array}$ & 333 & $46 \%$ \\
\hline Zaidi et al. 2007 [35] & UK & $\begin{array}{l}\text { Cross-sectional; } \\
\text { Survey }\end{array}$ & No & Yes & Yes & Labour ward staff & 45 & $100 \%$ \\
\hline Tamaddon et al. 2006 [36] & Sweden & $\begin{array}{l}\text { Cross-sectional; } \\
\text { Survey }\end{array}$ & No & Yes & Yes & ${ }^{b}$ Health professionals & 796 & $28 \%$ \\
\hline Jager et al. 2002 [37] & Switzerland & $\begin{array}{l}\text { Cross-sectional; } \\
\text { Survey }\end{array}$ & No & Yes & Yes & $\begin{array}{l}\text { Obstetricians and } \\
\text { gynaecologists }\end{array}$ & 454 & $39.1 \%$ \\
\hline
\end{tabular}

${ }^{a}$ Sample included paediatricians but did not report on paediatricians separately;

${ }^{b}$ Sample included paediatricians and paediatricians were compared with other professionals;

NA Not applicable

NR Not Reported 
Table 2 Assessment of methodological quality of studies included in the review

\begin{tabular}{|c|c|c|c|c|c|c|c|c|c|}
\hline \multirow[t]{2}{*}{ Reference } & \multicolumn{6}{|l|}{ Representativeness } & \multicolumn{2}{|c|}{ Survey validity } & \multirow[t]{2}{*}{ Score out of $\varepsilon$} \\
\hline & $\begin{array}{l}\text { Profession of } \\
\text { respondents described }\end{array}$ & $\begin{array}{l}\text { Age or years } \\
\text { of practice }\end{array}$ & Gender & Setting & $\begin{array}{l}\text { Sampling } \\
\text { procedure }\end{array}$ & $\begin{array}{l}\text { Response rate } \\
\text { reported }\end{array}$ & Pre-test & $\begin{array}{l}\text { Expert } \\
\text { review }\end{array}$ & \\
\hline \multicolumn{10}{|c|}{ Publications from African Countries } \\
\hline Ashimi et al. 2014 [21] & Yes & Yes & Yes & Yes & Yes & Yes & Yes & No & 7 \\
\hline Kaplan et al. 2013 [22] & Yes & Yes & Yes & Yes & No & No & Yes & Yes & 7 \\
\hline Ali et al. 2012 [23] & Yes & Yes & $\mathrm{No}^{\mathrm{a}}$ & Yes & No & No & No & No & 3 \\
\hline Dike et al. 2012 [24] & Yes & Yes & Yes & Yes & Yes & Yes & Yes & No & 7 \\
\hline Rasheed et al. 2011 [25] & Yes & No & No & Yes & No & Yes & No & No & 3 \\
\hline Refaat 2009 [26] & Yes & Yes & Yes & No & Yes & Yes & No & No & 5 \\
\hline Mostafa et al. 2006 [27] & Yes & Yes & Yes & Yes & Yes & Yes & No & No & 6 \\
\hline Onuh et al. 2006 [28] & Yes & Yes & Yes & Yes & Yes & Yes & Yes & No & 7 \\
\hline \multicolumn{10}{|c|}{ Publications from "Western Countries" } \\
\hline Caroppo et al. 2014 [29] & Yes & No & Yes & Yes & Yes & Yes & No & No & 5 \\
\hline Purchase et al. 2013 [30] & Yes & Yes & No & Yes & Yes & Yes & No & No & 5 \\
\hline Relph et al. 2013 [31] & Yes & Yes & Yes & Yes & Yes & Yes & Yes & No & 7 \\
\hline Moeed et al. 2012 [20] & Yes & No & No & No & Yes & Yes & No & No & 3 \\
\hline Hess et al. 2010 [32] & Yes & Yes & Yes & Yes & Yes & Yes & No & Yes & 7 \\
\hline Kaplan-Marcusan et al. 2009 [33] & Yes & Yes & Yes & Yes & Yes & Yes & No & No & 6 \\
\hline Leye 2008 [34] & Yes & Yes & Yes & Yes & Yes & Yes & Yes & Yes & 8 \\
\hline Zaidi et al. 2007 [35] & Yes & No & No & Yes & Yes & Yes & No & Yes & 5 \\
\hline Tamaddon et al. 2006 [36] & Yes & No & No & Yes & Yes & Yes & No & Yes & 5 \\
\hline Jager et al. 2002 [37] & Yes & No & No & Yes & Yes & Yes & No & No & 4 \\
\hline
\end{tabular}

"Yes" indicates that this criterion was adequately reported in the paper

"The sample consisted of "midwives" and it is assumed that all would have been female given the cultural setting for this study

\section{Participants}

Health professionals including paediatricians, obstetricians, gynaecologists, family doctors, nurses, midwives or students of medicine, nursing, midwifery or other health disciplines.

\section{Outcomes}

Measures of knowledge about FGM/C, attitudes/beliefs towards $\mathrm{FGM} / \mathrm{C}$ and experience of $\mathrm{FGM} / \mathrm{C}$ in clinical practice.

\section{Exclusion criteria}

- Publications reporting patient or community knowledge or attitudes

- Publications that used qualitative study designs

- Publications reporting on genital cosmetic procedures

- Foreign language publications

\section{Quality assessment}

Publications were assessed and scored for representativeness and survey tool validity. Quality measures included: sample description (1 point for each detail provided: profession, age, gender of respondents and response rate); sampling method (description of site/ setting - 1 point, sampling procedure described - 1 point); and survey validity (1 point if survey pre-tested and 1 point if the survey was reviewed by content experts), for a maximum score of eight points.

\section{Data extraction and analysis}

Data were extracted by two researchers independently (YZ, AP). Any inconsistencies were resolved by checking full-text versions of the documents and discussion with the review team. All proportions reported in the original documents have been rounded up to whole percentages for ease of reading and interpretation.

\section{Results}

One hundred and fifty nine potentially relevant articles were identified. After exclusion of duplicates there remained 122 unique publications. Editorials, letters, notes and publications that did not have abstracts (mainly opinion pieces) were excluded, leaving 109 
Table 3 Reported experience of FGMC in clinical practice

\begin{tabular}{|c|c|c|c|c|c|}
\hline Reference & Country & $\begin{array}{l}\text { Had seen patients } \\
\text { with FGMC }\end{array}$ & $\begin{array}{l}\text { Managed women or girls with } \\
\text { FGMC/FGMC complications; } \\
\text { used prevention measures }\end{array}$ & $\begin{array}{l}\text { Has performed FGMC or has } \\
\text { been asked to perform FGMC }\end{array}$ & $\begin{array}{l}\text { Clini } \\
\text { Clini } \\
\text { to su }\end{array}$ \\
\hline \multicolumn{6}{|c|}{ Publications from African Countries } \\
\hline \multirow[t]{2}{*}{ Kaplan et al. 2013 [22] } & \multirow[t]{2}{*}{ Gambia } & \multirow{2}{*}{$\begin{array}{l}41 \% \text { - had seen a girl } \\
\text { with complications of } \\
\text { FGM/C }\end{array}$} & \multirow{2}{*}{$\begin{array}{l}41 \% \text { - had seen a girl with } \\
\text { complications of FGM/C }\end{array}$} & $8 \%$ - had performed FGM/C & \multirow[t]{2}{*}{$N R^{a}$} \\
\hline & & & & $\begin{array}{l}69 \%-F G M / C \text { is practiced in } \\
\text { my family/household }\end{array}$ & \\
\hline \multirow[t]{2}{*}{ Ali et al. 2012 [23] } & \multirow[t]{2}{*}{ Sudan } & \multirow[t]{2}{*}{ NR } & \multirow[t]{2}{*}{ NR } & $\begin{array}{l}81 \% \text { had performed FGM/C } \\
\text { during their career }\end{array}$ & \multirow[t]{2}{*}{ NR } \\
\hline & & & & $\begin{array}{l}\text { Each of these midwives had } \\
\text { performed } 5-88 \text { FGM/C } \\
\text { procedures in the previous year }\end{array}$ & \\
\hline Rasheed et al. 2011 [25] & Egypt & NR & NR & $\begin{array}{l}\text { None of the nurses had } \\
\text { performed FGM/C }\end{array}$ & NR \\
\hline \multirow[t]{2}{*}{ Refaat 2009 [26] } & \multirow[t]{2}{*}{ Egypt } & \multirow[t]{2}{*}{ NR } & \multirow[t]{2}{*}{ NR } & $19 \%$ - performed FGM/C & \multirow[t]{2}{*}{ NR } \\
\hline & & & & $\begin{array}{l}34 \% \text { of those who perform } \\
\text { FGM/C reported } \\
\text { complications among } \\
\text { patients }\end{array}$ & \\
\hline \multirow[t]{3}{*}{ Onuh et al. 2006 [28] } & \multirow[t]{3}{*}{ Nigeria } & \multirow[t]{3}{*}{ NR } & \multirow[t]{3}{*}{ NR } & $7 \%$ - currently practice FGM/C & \multirow[t]{3}{*}{$N R$} \\
\hline & & & & $\begin{array}{l}14 \% \text { have practiced FGM/C } \\
\text { in the past }\end{array}$ & \\
\hline & & & & $\begin{array}{l}58 \% \text { - will perform FGMC in } \\
\text { the future if compelled to do so }\end{array}$ & \\
\hline
\end{tabular}

Publications from "Western Countries"

Caroppo et al. 2014 [29] Italy

Purchase et al. 2013 [30] UK

Relph et al. 2013 [31] UK

Moeed et al. 2012 [20] Australia and New Zealand
$71 \%$ - never met or assisted a woman with FGM/C despite working in an asylum seeker facility

$87 \%$ - had been involved in the care of a girl/woman with $\mathrm{FGM} / \mathrm{C}$

$20 \%$ - had seen $>10$ cases
$76 \%$ - stated they would refer the woman for care elsewhere, with many different options provided
3 midwives had been asked to perform FGM/C in a child or to re-infibulate after delivery
$34 \%$ were aware of guidelines/ procedures for the management of women with FGM/C

$26 \%$ - had sufficient training in FGMC

$31 \%$ - reported that the hospital/ trust had screening for FGM/C procedures

$21 \%$ - there was an FGM/C specialist (obstetrician or midwife) at the hospital trust

$40 \%$ - had training in deinfibulation

NR involved in the care of a woman with $\mathrm{FGM} / \mathrm{C}$

$76 \%$ see women

$47 \%$ had seen at least one from African countries woman or girl with and from the Middle East$$
\text { complications related to FGM }
$$

$21 \%$ - of O\&G specialists

NR
- "most commonly" urinary

problems; problems in labour and dyspareunia 
Table 3 Reported experience of FGMC in clinical practice (Continued)

\begin{tabular}{|c|c|c|c|c|c|}
\hline & & $\begin{array}{l}75 \% \text { saw at least one } \\
\text { woman with } \mathrm{FGM} / \mathrm{C} \\
\text { in the last } 5 \text { years }\end{array}$ & $\begin{array}{l}\text { "A few" reported psychosexual } \\
\text { complications }\end{array}$ & $\begin{array}{l}12 \% \text { - of those who had } \\
\text { been asked had done so: }\end{array}$ & \\
\hline & & \multirow[t]{5}{*}{$\begin{array}{l}\text { Most saw } 1-5 \text { women } \\
\text { with FGMC in the last } \\
5 \text { years }\end{array}$} & & $\begin{array}{l}38 \% \text { of the FGM/C workers } \\
\text { had heard of re-suturing tak- } \\
\text { ing place; one respondent in- } \\
\text { dicated that re-suturing had } \\
\text { taken place }>50 \text { times }\end{array}$ & \\
\hline & & & & $\begin{array}{l}2(0.5 \%) \text { respondents had } \\
\text { been asked to perform FGM/C } \\
\text { on a baby, young girl or } \\
\text { woman }\end{array}$ & \\
\hline & & & & $\begin{array}{l}\text { One was asked on 1-5 } \\
\text { occasions; the other 6-10 } \\
\text { occasions }\end{array}$ & \\
\hline & & & & $\begin{array}{l}1 \% \text { of the } O \& G \text { specialists } \\
\text { had convincing evidence that } \\
\text { the procedure was done in } \\
\text { Australia or NZ }\end{array}$ & \\
\hline & & & & $\begin{array}{l}10 \% \text { of the FGM/C workers } \\
\text { were aware of convincing } \\
\text { evidence that the procedure } \\
\text { was being performed in } \\
\text { Australia or NZ }\end{array}$ & \\
\hline \multirow[t]{3}{*}{ Hess et al. 2010 [32] } & \multirow[t]{3}{*}{ USA } & \multirow{3}{*}{$\begin{array}{l}43 \% \text { - of certified } \\
\text { nurse- midwives had } \\
\text { seen women with } \\
\text { FGM/C in their } \\
\text { practice }\end{array}$} & $\begin{array}{l}\text { Problems associated with } \\
\text { FGMC not discussed } \\
\text { consistently }\end{array}$ & & $N R$ \\
\hline & & & $\begin{array}{l}20 \% \text { discussed circumcision of } \\
\text { daughters, nieces, grand- } \\
\text { daughters "Often" or "Always" }\end{array}$ & & \\
\hline & & & $78 \%$ never discussed infertility & & \\
\hline \multirow[t]{7}{*}{$\begin{array}{l}\text { Kaplan-Marcusan et al. } \\
2009 \text { [33] }\end{array}$} & \multirow[t]{7}{*}{ Spain } & 2001 & NR & $\begin{array}{l}91 \% \text { of paediatricians had an } \\
\text { interest in } \mathrm{FGM} / \mathrm{C}\end{array}$ & NR \\
\hline & & $\begin{array}{l}6 \% \text { - of all HP } \\
\text { surveyed had seen } \\
\text { cases in practice }\end{array}$ & & $\begin{array}{l}42 \% \text { of paediatricians were } \\
\text { aware of guidelines and } \\
\text { protocols }\end{array}$ & \\
\hline & & $\begin{array}{l}7 \% \text { - of paediatricians } \\
\text { saw FGM/C }\end{array}$ & & & \\
\hline & & 2004 & & & \\
\hline & & $\begin{array}{l}16 \% \text { - had seen } \\
\text { FGMC in practice }\end{array}$ & & & \\
\hline & & $\begin{array}{l}19 \% \text { - of } \\
\text { paediatricians saw } \\
\text { FGM/C }\end{array}$ & & & \\
\hline & & $\begin{array}{l}\text { FGM/C was seen by } \\
\text { females more often } \\
\text { than males }\end{array}$ & & & \\
\hline \multirow[t]{3}{*}{ Leye 2008 [34] } & \multirow[t]{3}{*}{ Belgium } & $\begin{array}{l}58 \% \text { had seen } \\
\text { women or girls with } \\
\text { FGM/C in their } \\
\text { practice }\end{array}$ & $\begin{array}{l}\text { Consulted regarding } \\
\text { complications: }\end{array}$ & $\begin{array}{l}2 \%[6] \text { respondents had } \\
\text { been asked to perform FGM/C } \\
\text { in Belgium }\end{array}$ & \\
\hline & & Most common forms: & $1 \%$ - acute complications & $\begin{array}{l}4 \%[13] \text { had been asked } \\
\text { whether FGMC could be } \\
\text { performed in Belgium }\end{array}$ & $\begin{array}{l}51 \% \text { wanted } \\
\text { guidelines on } \\
\text { FGM/C }\end{array}$ \\
\hline & & 56 - infibulation & $2 \%$ - psychological problems & $\begin{array}{l}9.5 \% \text { [31] gynaecologists had } \\
\text { heard that FGM/C had been } \\
\text { performed in Belgium }\end{array}$ & $\begin{array}{l}45 \% \text { sought more } \\
\text { information about } \\
\text { FGM/C after seeing } \\
\text { patients with FGM/C }\end{array}$ \\
\hline
\end{tabular}


Table 3 Reported experience of FGMC in clinical practice (Continued)

\begin{tabular}{|c|c|c|c|c|c|}
\hline & & $3-$ sunna $^{b}$ & $4 \%$ - fistulae & & \\
\hline & & $\begin{array}{l}7 \text { patients, } 14 \text { years } \\
\text { old }\end{array}$ & $\begin{array}{l}15 \% \text { - pregnancy and delivery } \\
\text { problems }\end{array}$ & & \\
\hline & & $\begin{array}{l}23 \text { patients } 15-18 \\
\text { years old }\end{array}$ & $18 \%$ - chronic pain & & \\
\hline & & $\begin{array}{l}\text { The rest were } 19 \\
\text { years or older }\end{array}$ & $19 \%$ - urinary tract infections & & \\
\hline & & $\begin{array}{l}\text { Patients were from: } \\
\text { Somalia, Ethiopia, and } \\
\text { other including } \\
\text { Nigeria, Egypt, Mali, } \\
\text { Senegal }\end{array}$ & $41 \%$ - sexual dysfunction & & \\
\hline & & & $\begin{array}{l}35 \% \text { - of those looking after } \\
\text { pregnant women tried to } \\
\text { persuade the mother not to } \\
\text { perform FGMC if the child was } \\
\text { a daughter }\end{array}$ & & \\
\hline & & & $\begin{array}{l}65 \% \text { - said they would not do } \\
\text { any prevention }\end{array}$ & & \\
\hline Zaidi et al. 2007 [35] & UK & $\begin{array}{l}80 \% \text { had seen } \\
\text { women with FGM/C } \\
\text { in their practice }\end{array}$ & NR & NR & NR \\
\hline \multirow[t]{3}{*}{ Tamaddon et al. 2006 [36] } & \multirow[t]{3}{*}{ Sweden } & \multirow[t]{3}{*}{$\begin{array}{l}60 \% \text { had seen at } \\
\text { least one patient with } \\
\text { FGM/C }\end{array}$} & $\begin{array}{l}39 \% \text { - had seen patients with } \\
\text { long-term complications of } \\
\text { FGM/C }\end{array}$ & $\begin{array}{l}5 \% \text { - had been asked about } \\
\text { performing FGM/C in } \\
\text { Sweden; } 4 \text { of these were } \\
\text { paediatricians }\end{array}$ & \multirow[t]{3}{*}{ NR } \\
\hline & & & $\begin{array}{l}1 \% \text { - had seen patients with } \\
\text { complications due to recently } \\
\text { performed FGC }\end{array}$ & $\begin{array}{l}10 \% \text { - had been asked to } \\
\text { perform reinfibulation after } \\
\text { birth }\end{array}$ & \\
\hline & & & $\begin{array}{l}2 \text { of these } 7 \text { were } \\
\text { paediatricians, } 4 \text { midwives, } 1 \\
\text { gyneacologist }\end{array}$ & & \\
\hline \multirow[t]{4}{*}{ Jager et al. 2002 [37] } & \multirow[t]{4}{*}{ Switzerland } & $\begin{array}{l}51 \% \text { - had seen } \\
\text { women with FGM/C } \\
\text { in their practice in } \\
\text { Switzerland }\end{array}$ & NR & $\begin{array}{l}21 \% \text { - had been asked to re- } \\
\text { infibulated after birth }\end{array}$ & $\begin{array}{l}\mathrm{FGM} / \mathrm{C} \text { is not } \\
\text { included in the } \\
\text { undergraduate } \\
\text { medical } \\
\text { curriculum }\end{array}$ \\
\hline & & \multirow{3}{*}{$\begin{array}{l}73 \% \text { - from the } \\
\text { French-speaking } \\
\text { region of Switzerland } \\
\text { had seen women } \\
\text { with FGM/C in their } \\
\text { practice }\end{array}$} & & $\begin{array}{l}2 \text { gyneacologists have been } \\
\text { asked to perform FGM/C in } \\
\text { young girls }\end{array}$ & \multirow[t]{3}{*}{$\begin{array}{l}\text { There is no } \\
\text { reporting system } \\
\text { for FGM/C }\end{array}$} \\
\hline & & & & $\begin{array}{l}4 \text { gyneacologists were asked } \\
\text { where FGMC could be } \\
\text { performed in Switzerland }\end{array}$ & \\
\hline & & & & $\begin{array}{l}12 \text { gyneacologists said that } \\
\text { they knew of FGM/C being } \\
\text { performed in Switzerland }\end{array}$ & \\
\hline
\end{tabular}

${ }^{\mathrm{a} N R}=$ Not reported; ${ }^{\mathrm{b}}$ Sunna- Equivalent to the WHO Type 1 - cliteridectomy

abstracts for screening. Of the 109 abstracts screened, 67 did not study health professionals and 19 were reviews which did not include primary data. Twenty-three full text articles were reviewed in detail and 5 of these were excluded because they used qualitative methods, leaving 18 articles for analysis (Fig. 1) [20-37].

Of the 18 publications, eight originated from lowmiddle income countries in Africa, mainly from Nigeria and Egypt (Table 1). Ten came from high income countries: five from Europe, three from the UK, one from Australia/New Zealand (ANZ), and one from the USA (Table 1). We found no studies that specifically focussed on paediatricians. Four studies reported on mixed samples, which included paediatricians, but only two of these analysed paediatricians as a separate subgroup (Table 1). Seventeen studies reported on health professionals' knowledge, 13 on practice and 12 on attitudes, with only four studies 
Table 4 Health professionals' reported knowledge about FGMC

\begin{tabular}{|c|c|c|c|c|}
\hline Reference & Country & $\begin{array}{l}\text { Knowledge of FGM/C; } \\
\text { FGM/C types; high risk } \\
\text { groups }\end{array}$ & Knowledge about complications & $\begin{array}{l}\text { Knowledge about legislation / } \\
\text { clinical guidelines }\end{array}$ \\
\hline \multicolumn{5}{|c|}{ Publications from African Countries } \\
\hline \multirow[t]{5}{*}{ Ashimi et al. 2014 [21] } & \multirow[t]{5}{*}{ Nigeria } & $91 \%$ - had heard of FGM/C & $77 \%$ - haemorrhage & \multirow[t]{5}{*}{$N R^{a}$} \\
\hline & & $\begin{array}{l}40 \% \text { - did not know any } \\
\text { of the } 4 \text { types }\end{array}$ & $\begin{array}{l}73 \% \text { - transmission of infectious disease } \\
\text { (HIV, hepatitis and tetanus) }\end{array}$ & \\
\hline & & \multirow{3}{*}{$\begin{array}{l}49 \% \text { identified "Angurya } \\
\text { and Gishiri"'b as forms of } \\
\text { FGM/C }\end{array}$} & $63 \%$ - sexual dysfunction & \\
\hline & & & $54 \%$ - difficult birth & \\
\hline & & & $48 \%$ - epidermal cysts & \\
\hline \multirow[t]{5}{*}{ Kaplan et al. 2013 [22] } & \multirow[t]{5}{*}{ Gambia } & \multirow[t]{5}{*}{ NR } & $53 \%$ - haemorrhage & \multirow[t]{5}{*}{ NR } \\
\hline & & & $59 \%$ - transmission of infectious disease & \\
\hline & & & $46 \%$ - difficult birth & \\
\hline & & & $25 \%$ - sexual dysfunction & \\
\hline & & & $\begin{array}{l}21 \% \text { - affects health and welfare of } \\
\text { women and girls }\end{array}$ & \\
\hline \multirow[t]{3}{*}{ Ali et al. 2012 [23] } & \multirow[t]{3}{*}{ Sudan } & $\begin{array}{l}7 \% \text { - identified all } 4 \text { types } \\
\text { correctly }\end{array}$ & $\begin{array}{l}46 \% \text { - transmission of infectious disease } \\
(\mathrm{HIV})\end{array}$ & $25.5 \%-F G M / C$ is illegal \\
\hline & & \multirow{2}{*}{$\begin{array}{l}545 \% \text { - identified type } 1 \\
\text { correctly }\end{array}$} & $64 \%$ - sexual dysfunction & \multirow[t]{2}{*}{$74.5 \%-F G M / C$ is legal } \\
\hline & & & $29 \%$ - infertility & \\
\hline \multirow[t]{4}{*}{ Dike et al. 2012 [24] } & \multirow[t]{4}{*}{ Nigeria } & \multirow[t]{4}{*}{ NR } & $86 \%$ - haemorrhage & $\begin{array}{l}100 \%-F G M / C \text { is banned in some } \\
\text { states }\end{array}$ \\
\hline & & & $84 \%$ - transmission of infectious disease (HIV) & \multirow{3}{*}{$\begin{array}{l}96 \% \text { - FGM/C is a crime against } \\
\text { humanity }\end{array}$} \\
\hline & & & $27 \%$ - difficult birth & \\
\hline & & & $7 \%$ - sexual dysfunction & \\
\hline Rasheed et al. 2011 [25] & Egypt & NR & $\begin{array}{l}66 \% \text { - knew about complications of } \\
\text { FGM/C }\end{array}$ & NR \\
\hline \multirow[t]{5}{*}{ Refaat 2009 [26] } & \multirow[t]{5}{*}{ Egypt } & \multirow{5}{*}{$\begin{array}{l}76 \% \text { - know the type } \\
\text { usually performed in Egypt } \\
\text { (type II) }\end{array}$} & $75 \%$ - haemorrhage & \multirow[t]{5}{*}{ NR } \\
\hline & & & $70 \%$ - sexual dysfunction & \\
\hline & & & $64 \%$ - shock & \\
\hline & & & $63 \%$ - genital disfigurement & \\
\hline & & & $\begin{array}{l}14 \% \text { - NO complications (if done by a } \\
\text { physician or gynaecologist) }\end{array}$ & \\
\hline \multirow[t]{5}{*}{ Mostafa et al. 2006 [27] } & \multirow[t]{5}{*}{ Egypt } & $\begin{array}{l}52 \% \text { - correctly identified } \\
\text { type I }\end{array}$ & $\begin{array}{l}62 \% \text { - aware that FGMC can cause } \\
\text { complications including: }\end{array}$ & $\begin{array}{l}17 \% \text { - knew Egyptian law which } \\
\text { states that FGM/C cannot be } \\
\text { performed by a non-physician }\end{array}$ \\
\hline & & $30 \%$ - identified type II & $48 \%$ - short-term physical & \multirow{4}{*}{$\begin{array}{l}28 \% \text { - reported that FGM/C } \\
\text { violates the medical ethical } \\
\text { principles of "do no harm" and "no } \\
\text { not kill" }\end{array}$} \\
\hline & & \multirow[t]{3}{*}{$5 \%$ - identified type III } & $39 \%$ - long term physical & \\
\hline & & & $62 \%$ - psychosocial complications & \\
\hline & & & $59 \%$ - sexual dysfunction & \\
\hline \multirow[t]{7}{*}{ Onuh et al. 2006 [28] } & \multirow[t]{7}{*}{ Nigeria } & $\begin{array}{l}100 \% \text { - identified at least } \\
\text { one type of FGMC }\end{array}$ & $98 \%$ - haemorrhage & \multirow[t]{7}{*}{ NR } \\
\hline & & $\begin{array}{l}38 \% \text { - identified Type I and } \\
\text { Type II ONLY as FGM/C }\end{array}$ & $81 \%$ - transmission of infectious disease & \\
\hline & & $7 \%$ - identified all 4 types & $54 \%$ - transmission of HIV & \\
\hline & & & $80 \%$ - difficult birth & \\
\hline & & & $55 \%$ - scars and keloid formation & \\
\hline & & & $21 \%$ - infertility & \\
\hline & & & $59 \%$ - sexual dysfunction & \\
\hline
\end{tabular}


Table 4 Health professionals' reported knowledge about FGMC (Continued)

Publications from "Western Countries"

Caroppo et al. 2014 [29] Italy

Purchase et al. 2013 [30] UK

Relph et al. 2013 [31] UK

Hess et al. 2010 [32]

Kaplan-Marcusan et al. Spain 2009 [33]

Leye 2008 [34]
$9 \%$ - knew that there are different types of FGM/C depending on the woman's country of origin

NR

$100 \%$ - aware of the practice of FGM/C

$58 \%$ - knew there are 4 types of FGM/C

$93 \%$ of senior doctors

$50 \%$ of junior doctors

$40 \%$ - confident in diagnosing FGM/C

$18 \%$ - knew that both Muslim and Christian women may have FGM/C

$39 \%$ - knew FGM/C is NOT required by either religion

Nurse midwives with direct practice experience of

FGM/C scored better on a knowledge test

$97 \%$ knew what $\mathrm{FGM} / \mathrm{C}$ is NR

Able to identify the 4

types:

$41 \%$ - of all professionals

$68 \%$ - of O\&G

$55 \%$ - of paediatricians

$38 \%$ - general medicine

$79 \%$ - said they knew high risk countries

$22 \%$ - actually able to identify the high risk countries
$5 \%$ - knew how to manage a woman with FGMC

$92 \%$ - identified each of the long term complications

$75 \%$ - HIV/hepatitis risk

$74 \%$ - pelvic infection

$10 \%$ - associated psychiatric syndromes

To prevent complications during labour:

$74 \%$ - knew that defibulation should take place pre-conception

$31 \%$ - knew that defibulation is recommended at $\sim 20$ weeks pregnancy $52 \%$ - unaware of referral pathways

$76 \%$ - haemorrahge

$32 \%$ - knew that defibulation should be performed before pregnancy to avoid complications

$71 \%$ - of nurse midwives who did not have direct experience with FGMC knew about FGMC complications, compared with $89 \%$ of those who had direct experience

Over a half of respondents did not know that circumcised women avoid health care due to stigma and legal implications
$44 \%$ - knew that Italy has a law prohibiting FGMC practice

$94 \%$ - FGM/C always illegal in the UK

$79 \%$ - were aware of the FGM/C Act

$84 \%$ - knew to contact a child protection officer if they thought a child was at risk

$72 \%$ - aware of UK legislation on FGM/C

$89 \%$ - family/religious figure performing $\mathrm{FGM} / \mathrm{C}$ in UK is illegal

$77 \%$ - UK doctor performing $\mathrm{FGM} / \mathrm{C}$ in UK is illegal

$67 \%$ - reinfibulation after delivery is illegal

$78 \%$ - sending a child abroad for $\mathrm{FGM} / \mathrm{C}$ is illegal

$56 \%$ - knew that it is illegal to perform $\mathrm{FGM} / \mathrm{C}$ in girls and young women aged $<18$ years

$20 \%$ - aware of protocols or guidelines

$42 \%$ - of paediatricians aware of protocols or guidelines
$46 \%$ - knew that FGM/C was illegal in Belgium 
Table 4 Health professionals' reported knowledge about FGMC (Continued)

\begin{tabular}{|c|c|c|c|c|}
\hline & & & & $\begin{array}{l}24 \% \text { - knew which types of FGM/C } \\
\text { were included under the law }\end{array}$ \\
\hline & & & & $\begin{array}{l}1 \% \text { ( } 4 \text { respondents) - knew of } \\
\text { guidelines and information about } \\
\text { FGM/C in their hospital }\end{array}$ \\
\hline \multirow[t]{5}{*}{ Zaidi et al. 2007 [35] } & \multirow[t]{5}{*}{ UK } & $\begin{array}{l}98 \% \text { - knew what FGMC } \\
\text { was }\end{array}$ & $\begin{array}{l}84 \% \text { - knew of complications associated } \\
\text { with FGMC }\end{array}$ & \multirow[t]{5}{*}{$\begin{array}{l}40 \% \text { - knew the details of the UK } \\
\text { FGM/C Act }\end{array}$} \\
\hline & & $\begin{array}{l}42 \% \text { - knew that there } \\
\text { were different types of } \\
\text { FGMC }\end{array}$ & $\begin{array}{l}70 \% \text { - knew that the best time for } \\
\text { defibulation was before pregnancy (if } \\
\text { FGMC diagnosed before pregnancy) }\end{array}$ & \\
\hline & & $\begin{array}{l}4 \% \text { - correctly classified } \\
\text { the } 4 \text { types }\end{array}$ & $\begin{array}{l}80 \% \text { - knew that defibulation should be } \\
\text { done during pregnancy if diagnosed } \\
\text { during pregnancy }\end{array}$ & \\
\hline & & $\begin{array}{l}84 \% \text { - knew the high risk } \\
\text { groups }\end{array}$ & \multirow{2}{*}{$\begin{array}{l}54 \% \text { - knew that an anterior episiotomy } \\
\text { should be performed if the woman is in } \\
\text { the } 2^{\text {nd }} \text { stage of labour }\end{array}$} & \\
\hline & & $\begin{array}{l}58 \% \text { - were NOT aware } \\
\text { that women at risk should } \\
\text { be identified during } \\
\text { antenatal visits }\end{array}$ & & \\
\hline \multirow[t]{2}{*}{ Tamaddon et al. 2006 [36] } & \multirow[t]{2}{*}{ Sweden } & $\begin{array}{l}28 \% \text { - said they had } \\
\text { adequate knowledge } \\
\text { about FGM/C }\end{array}$ & \multirow[t]{2}{*}{ NR } & \multirow[t]{2}{*}{ NR } \\
\hline & & $\begin{array}{l}20 \% \text { - of paediatricians } \\
\text { said they had adequate } \\
\text { knowledge about FGM/C }\end{array}$ & & \\
\hline Jager et al. 2002 [37] & Switzerland & NR & NR & $\begin{array}{l}\text { Representatives from the } \\
\text { Departments of Health in each } \\
\text { Canton, did not know of any } \\
\text { guidelines on FGM/C in their } \\
\text { Canton }\end{array}$ \\
\hline
\end{tabular}

${ }^{\mathrm{a}} \mathrm{NR}=$ Not reported ${ }^{\mathrm{b}}$ Angurya: is a form of FGMC type 4 that involves the scraping of tissue around the vaginal opening. Gishiri: is a form of FGMC type 4 where a long knife is inserted into the vagina and backward cuts from the vagina's anterior wall into the perineum are made

from high income countries reporting on health professionals' attitudes (Table 1).

\section{Quality assessment}

Publications were scored according to our pre-determined quality assessment matrix (Table 2). Only one publication scored the maximum eight points. Twelve $(67 \%)$ papers described the age of the participants and 11(61\%) reported gender. A description of the setting was lacking in two studies, sampling procedures were not described in three. (Table 2). Six (33 \%) of the surveys were pre-tested, five (22\%) were reviewed by content experts, and two (11 $\%)$ were both pre-tested and reviewed by a content expert. Nine studies did not report any survey validation. Most of the studies are unlikely to be representative. Three studies from high income countries were set in specialist facilities serving migrant communities in which FGM/C is common and the health professionals surveyed had frequent experience with women affected by FGM/C.[29, 31, 35] Two studies did not report a response rate and in 5 studies the response rate was $<50 \%$, (Table 1 ).
1. Do health professionals have experience with FGM/ $\mathrm{C}$ in their clinical practice?

Five surveys in high income countries reported that health professionals who responded provided care to women with FGM/C, including $75.3 \%$ of obstetricians/ gynaecologists in ANZ [20]; $40 \%$ of nurse-midwives in the USA [32]; $50 \%$ of Swiss obstetricians/gynaecologists [37]; $60 \%$ of Swedish health providers including paediatricians [36]; $12 \%$ of paediatricians, $80 \%$ of gynaecologists responding to a Spanish survey [33]; and $58 \%$ of Belgian gynaecologists [34], ( Table 3). Despite working in an asylum seeker health service in Italy, which serves refugees from high prevalence countries, $71 \%$ of health professionals reported that they had never met or assisted a woman with FGM/C [29].

Some obstetricians, gynaecologists and midwives working in high income countries had been asked to re-infibulate women after delivery and some had done so (Table 4). Four studies reported that health professionals in high income countries had been asked to perform $\mathrm{FGM} / \mathrm{C}$ in babies or young girls, or to 
Table 5 Health professionals' attitudes towards FGMC

\begin{tabular}{|c|c|c|c|c|}
\hline Reference & Country & $\begin{array}{l}\text { Beliefs about the reasons for performing } \\
\text { FGM/C }\end{array}$ & $\begin{array}{l}\text { Support for and intentions for performing } \\
\text { FGM/C }\end{array}$ & $\begin{array}{l}\text { Beliefs and attitudes } \\
\text { about the law and } \\
\text { educational needs }\end{array}$ \\
\hline \multicolumn{5}{|c|}{ Publications from African Countries } \\
\hline \multirow[t]{5}{*}{ Ashimi et al. 2014 [21] } & \multirow[t]{5}{*}{ Nigeria } & $53 \%$ - prevent promiscuity & $4 \%$ would support FGM/C & \multirow[t]{5}{*}{$N R^{a}$} \\
\hline & & $28 \%$ - preserve virginity & $4 \%$ would perform FGM/C & \\
\hline & & $16 \%$ - socio-cultural acceptance & \multirow{3}{*}{$\begin{array}{l}4 \% \text { of respondents (all women) would } \\
\text { allow daughters to undergo FGM/C }\end{array}$} & \\
\hline & & $10 \%$ - religious reasons & & \\
\hline & & $8 \%$ - medically beneficial & & \\
\hline \multirow[t]{7}{*}{ Kaplan et al. 2013 [22] } & \multirow[t]{7}{*}{ Gambia } & $54 \%$ - mandatory religious practice & $\begin{array}{l}43 \% \text { - were supportive of the } \\
\text { continuation of FGM/C practice }\end{array}$ & \multirow[t]{7}{*}{ NR } \\
\hline & & $48 \%$ - cultural practice & $\begin{array}{l}47 \% \text { - intended to subject their daughters } \\
\text { to FGM/C }\end{array}$ & \\
\hline & & $14 \%$ - preserve virginity & $\begin{array}{l}43 \% \text { - medicalising FGMC would make } \\
\text { the practice safer }\end{array}$ & \\
\hline & & \multirow[t]{4}{*}{$1 \%$ - it does not violate human rights } & $\begin{array}{l}73 \% \text { - Health care workers have a role in } \\
\text { eliminating FGMC }\end{array}$ & \\
\hline & & & $\begin{array}{l}55 \%-F G M / C \text { cannot be eliminated in } \\
\text { The Gambia }\end{array}$ & \\
\hline & & & $\begin{array}{l}78 \% \text { - men should be involved in the } \\
\text { debate about FGM/C }\end{array}$ & \\
\hline & & & $\begin{array}{l}13 \% \text { - girls that have not undergone } \\
\text { FGM/C should be discriminated against }\end{array}$ & \\
\hline \multirow[t]{3}{*}{ Ali et al. 2012 [23] } & \multirow[t]{3}{*}{ Sudan } & $51.2 \%$ - cultural & $19 \%$ - all forms of FGM/C are harmful & \multirow[t]{3}{*}{ NR } \\
\hline & & $26 \%$ - religious & $76 \%$ - only some forms are harmful & \\
\hline & & $23 \%$ - economic & $5 \%$ - all forms are not harmful & \\
\hline \multirow[t]{5}{*}{ Dike et al. 2012 [24] } & \multirow[t]{5}{*}{ Nigeria } & $51 \%$ - prevent promiscuity & $\begin{array}{l}100 \% \text { would NOT have their daughters } \\
\text { undergo FGM/C }\end{array}$ & To stop FGM/C: \\
\hline & & $47 \%$ - appearance of external genitalia & & $\begin{array}{l}81 \% \text { - Public } \\
\text { enlightenment needed }\end{array}$ \\
\hline & & $27 \%$ - tradition & & $\begin{array}{l}25 \% \text { - Counselling of } \\
\text { parents }\end{array}$ \\
\hline & & $11 \%$ - initiation into womanhood & & $7 \%$ - punishing any \\
\hline & & $7 \%$ - spiritual satisfaction & & abets the practice \\
\hline \multirow[t]{8}{*}{ Rasheed et al. 2011 [25] } & \multirow[t]{8}{*}{ Egypt } & $\begin{array}{l}100 \% \text { - senior physicians believed FGM/C } \\
\text { prescribed by religion }\end{array}$ & Nurses: & \multirow[t]{8}{*}{ NR } \\
\hline & & $\begin{array}{l}97 \% \text { - young physicians believed FGM/C } \\
\text { prescribed by religion }\end{array}$ & $88 \%$ - supported the practice of FGM/C & \\
\hline & & $\begin{array}{l}88 \% \text { - nurses believe it is a traditional } \\
\text { practice }\end{array}$ & $\begin{array}{l}48 \% \text { - would have their daughters } \\
\text { undergo FGM/C }\end{array}$ & \\
\hline & & & $28 \%$ - had their daughters undergo FGM/C & \\
\hline & & & Young Physicians: & \\
\hline & & & $34 \%$ - supported the practice of FGM/C & \\
\hline & & & Senior physicians: & \\
\hline & & & $15 \%$ - supported the practice & \\
\hline \multirow[t]{2}{*}{ Refaat 2009 [26] } & \multirow[t]{2}{*}{ Egypt } & $82 \%$ - do NOT approve of the practice & $\begin{array}{l}18 \% \text { - supported practice; reasons for } \\
\text { continuing practice included: }\end{array}$ & $\begin{array}{l}91 \%-\mathrm{FGM} / \mathrm{C} \text { and } \\
\text { complications should be } \\
\text { taught at medical } \\
\text { school }\end{array}$ \\
\hline & & $\begin{array}{l}\text { Those practising in the Upper Egypt } \\
\text { area, those from rural areas and those }\end{array}$ & - Convinced of benefit & $\begin{array}{l}40 \% \text { believed that } \\
\text { physicians are the most }\end{array}$ \\
\hline
\end{tabular}


Table 5 Health professionals' attitudes towards FGMC (Continued)

\begin{tabular}{|c|c|c|c|c|}
\hline & & \multirow{4}{*}{$\begin{array}{l}\text { with a diploma (rather than PhD or } \\
\text { Fellowship) were more likely to approve } \\
\text { the practice of FGM/C }\end{array}$} & & $\begin{array}{l}\text { appropriate to perform } \\
\text { FGM/C }\end{array}$ \\
\hline & & & - Profit & \multirow{9}{*}{$\begin{array}{l}35 \% \text { did NOT approve } \\
\text { of the law banning } \\
\text { FGM/C }\end{array}$} \\
\hline & & & - Harm reduction & \\
\hline & & & $\begin{array}{l}82 \% \text { - did NOT approve of the practice } \\
\text { for the following reasons: }\end{array}$ & \\
\hline & & \multirow{6}{*}{$\begin{array}{l}18 \% \text { - supported practice for religious or } \\
\text { customary reasons }\end{array}$} & $75 \%$ - reduced sexual pleasure & \\
\hline & & & $64 \%$ - pain & \\
\hline & & & $61 \%$ - bad habit & \\
\hline & & & $52 \%$ - not religious practice & \\
\hline & & & $49 \%$ - causes health problems & \\
\hline & & & $48 \%$ - against women's dignity & \\
\hline \multirow[t]{8}{*}{ Mostafa et al. 2006 [27] } & \multirow[t]{8}{*}{ Egypt } & $\begin{array}{l}51 \% \text { - NO medical reason for } \\
\text { performing FGM/C }\end{array}$ & $\begin{array}{l}43 \% \text { - unethical for a health professional } \\
\text { to damage a healthy body }\end{array}$ & $\begin{array}{l}50 \% \text { - medicalization is } \\
\text { the first step to } \\
\text { prevention of the } \\
\text { practice }\end{array}$ \\
\hline & & $\begin{array}{l}45 \%-F G M / C \text { is a violation of human } \\
\text { rights }\end{array}$ & $65 \%-F G M / C$ is NOT a health issue & $\begin{array}{l}23 \% \text { - believed that the } \\
\text { law is enough for } \\
\text { prevention }\end{array}$ \\
\hline & & $34 \%-F G M / C$ is essential part of culture & $\begin{array}{l}32 \% \text { - would subject their future } \\
\text { daughters to this practice }\end{array}$ & \multirow{6}{*}{$\begin{array}{l}53 \% \text { - believe that laws } \\
\text { must go hand in hand } \\
\text { with community } \\
\text { education }\end{array}$} \\
\hline & & $\begin{array}{l}24 \% \text { - FGM/C prevents external genitalia } \\
\text { from growing }\end{array}$ & $\begin{array}{l}58 \% \text { - would NOT object if family } \\
\text { members were to subject their daughters } \\
\text { to FGM/C }\end{array}$ & \\
\hline & & 20 \% FGM/C ensures a girl's virginity & $73 \%$ - FGM/C should be medicalised & \\
\hline & & $49 \%$ - prevents promiscuity & $91 \%$ - medicalization favourable because & \\
\hline & & $30 \%-F G M / C$ is a religious obligation & $\begin{array}{l}\text { It reduces pain; carried out under hygienıc } \\
\text { conditions and with anaesthetic }\end{array}$ & \\
\hline & & $\begin{array}{l}86 \% \text { - believed that FGMC is practiced } \\
\text { only by Muslims }\end{array}$ & & \\
\hline \multirow[t]{4}{*}{ Onuh et al. 2006 [28] } & \multirow[t]{4}{*}{ Nigeria } & $9 \%$ - decreases promiscuity & $\begin{array}{l}4 \% \text { - will have their own daughters } \\
\text { undergo FGMC }\end{array}$ & \multirow[t]{4}{*}{$\begin{array}{l}92 \% \text { - FGM/C should } \\
\text { be legislated against }\end{array}$} \\
\hline & & $10 \%$ - makes genitalia more attractive & $3 \%-F G M / C$ is a good practice & \\
\hline & & \multirow{2}{*}{$\begin{array}{l}\text { Other reasons: - cultural; financial; } \\
\text { patient safeguarding from "traditional } \\
\text { circumcisers" }\end{array}$} & $3 \%$ - will encourage FGM/C & \\
\hline & & & $\begin{array}{l}24 \% \text { - some forms of FGM/C are not } \\
\text { harmful }\end{array}$ & \\
\hline \multicolumn{5}{|c|}{ Publications from "Western Countries" } \\
\hline \multirow[t]{2}{*}{ Purchase et al. 2013 [30] } & \multirow[t]{2}{*}{ UK } & $76 \%$ - cultural reasons & NR & \multirow[t]{2}{*}{ NR } \\
\hline & & $16 \%$ - religious reasons & & \\
\hline \multirow[t]{2}{*}{ Relph et al. 2013 [31] } & \multirow[t]{2}{*}{ UK } & \multirow[t]{2}{*}{$100 \%$ - cultural reasons } & $\begin{array}{l}9 \% \text { - FGM/C should be medicalized to } \\
\text { reduce complications }\end{array}$ & \multirow{2}{*}{$\begin{array}{l}87 \% \text { - would warn } \\
\text { social services of a child } \\
\text { in danger of FGM/C }\end{array}$} \\
\hline & & & $\begin{array}{l}18 \% \text { - would support a woman's request } \\
\text { for re-infibulation after birth if this was } \\
\text { legal in the UK }\end{array}$ & \\
\hline \multirow[t]{2}{*}{ Moeed et al. 2012 [20] } & \multirow[t]{2}{*}{$\begin{array}{l}\text { Australia } \\
\text { and New } \\
\text { Zealand }\end{array}$} & \multirow[t]{2}{*}{$N R$} & $\begin{array}{l}21 \% \text { - O\&G specialists believed that in the } \\
\text { women and girls with FGMC seen by } \\
\text { them, the FGM/C was probably done in } \\
\text { Australia (but they did not provide } \\
\text { number estimates) }\end{array}$ & \multirow[t]{2}{*}{ NR } \\
\hline & & & $\begin{array}{l}42 \% \text { of the FGM/C workers believed that } \\
\text { the women and children with FGMC } \\
\text { probably had the procedure performed in } \\
\text { Australia/NZ }\end{array}$ & \\
\hline
\end{tabular}


Table 5 Health professionals' attitudes towards FGMC (Continued)

\begin{tabular}{|c|c|c|c|c|}
\hline & & & $\begin{array}{l}26 \% \text { of FGMC/C workers believed that } \\
\text { children were being taken out of Australia } \\
\text { to attend family celebrations and to have } \\
\text { FGM/C done overseas }\end{array}$ & \\
\hline \multirow[t]{8}{*}{$\begin{array}{l}\text { Kaplan-Marcusan } \\
\text { et al. } 2009 \text { [33] }\end{array}$} & \multirow[t]{8}{*}{ Spain } & $50 \%$ - traditional reasons & \multirow[t]{8}{*}{ NR } & $\begin{array}{l}2001-1 \% \text { said ignore } \\
\text { the problem }\end{array}$ \\
\hline & & \multirow[t]{7}{*}{$16 \%$ - religious reasons } & & $48 \%$ - educate \\
\hline & & & & $\begin{array}{l}32 \% \text { - educate and } \\
\text { report }\end{array}$ \\
\hline & & & & $\begin{array}{l}19 \% \text { - report to } \\
\text { authorities }\end{array}$ \\
\hline & & & & $\begin{array}{l}2004 \text { - None said } \\
\text { ignore }\end{array}$ \\
\hline & & & & $\begin{array}{l}49 \% \text { - educate and } \\
\text { report }\end{array}$ \\
\hline & & & & $27 \%$ - educate \\
\hline & & & & $\begin{array}{l}24 \% \text { - report to } \\
\text { authorities }\end{array}$ \\
\hline \multirow[t]{7}{*}{ Leye 2008 [34] } & \multirow[t]{7}{*}{ Belgium } & \multirow[t]{7}{*}{ NR } & $\begin{array}{l}86 \%-F G M / C \text { is a form of violence } \\
\text { against women }\end{array}$ & $\begin{array}{l}21 \% \text { - believed that } \\
\text { FGM/C performed by a } \\
\text { medical practitioner } \\
\text { would reduce harm }\end{array}$ \\
\hline & & & $\begin{array}{l}61 \%-F G M / C \text { is a violation of human } \\
\text { rights }\end{array}$ & \multirow{6}{*}{$\begin{array}{l}48 \% \text { - wanted more } \\
\text { clarity around ethico- } \\
\text { legal issues }\end{array}$} \\
\hline & & & $\begin{array}{l}7 \%-\text { FGM/C should be respected because } \\
\text { of cultural and religious beliefs }\end{array}$ & \\
\hline & & & $\begin{array}{l}77 \% \text { - considered re-infubulation as a } \\
\text { form of FGM/C }\end{array}$ & \\
\hline & & & $\begin{array}{l}19 \% \text { - would re-infibulate if requested by } \\
\text { the woman }\end{array}$ & \\
\hline & & & $\begin{array}{l}47 \% \text { - a symbolic incision was a good } \\
\text { alternative to FGM/C }\end{array}$ & \\
\hline & & & $\begin{array}{l}15 \% \text { - Genital piercings and vaginal } \\
\text { cosmetic surgery considered a type of } \\
\text { FGM/C }\end{array}$ & \\
\hline
\end{tabular}

${ }^{\mathrm{a}} \mathrm{NR}=$ Not reported

provide information about where to get $\mathrm{FGM} / \mathrm{C}$ procedures done: two respondents to the ANZ survey [20]; 6 respondents to the Belgian study [34]; two respondents to the Swiss survey [37] and seven health professionals including two paediatricians in a Swedish survey [36] (Table 3).

Survey respondents in high income countries reported that they knew that FGM/C was being practised in children including in Belgium and Switzerland [34, 37]. Approximately $20 \%$ of obstetricians/gynaecologists responding to the ANZ survey believed that women presenting to them with $\mathrm{FGM} / \mathrm{C}$ probably had the procedure done in Australia or New Zealand [20].

Five surveys of health professionals in Nigeria [28], Egypt [25, 26], Gambia [22] and the Sudan [23] reported on whether the respondents had performed or had been asked to perform FGM/C procedures (Table 3). The study of Sudanese midwives reported that $81 \%$ of respondents had performed FGM/C multiple times [23]. In contrast, among nurses and community midwives surveyed in Gambia, only $7.6 \%$ had performed the procedure but $68.6 \%$ said that FGM/C was practiced in their household or family [22]. Among nurses surveyed in Nigeria, $7 \%$ currently practiced FGM, $14 \%$ had practiced in the past and $58 \%$ said they would perform FGM/C if required [24]. None of the nurses surveyed in Egypt [25] had performed FGM/C, but $19.2 \%$ of Egyptian doctors surveyed had performed $\mathrm{FGM} / \mathrm{C}$ and of these $24 \%$ reported complications due to $\mathrm{FGM} / \mathrm{C}[26]$.

2. Do health professionals have adequate knowledge about FGM/C types, complications, high risk groups and do they have access to education and training opportunities? 
Knowledge about the FGM/C types varied widely; few health professionals in high income countries knew that there were 4 different types of FGM/C and fewer were able to identify the 4 types (Table 4 ). The Spanish study was an exception with $85 \%$ of O\&G and $55 \%$ of paediatricians able to identify the 4 types of FGM/C [33]. Knowledge of the 4 types of FGM/C was also poor among respondents surveyed in Africa, however, most respondents knew of the type of FGM most commonly practised in their local area e.g. $76 \%$ of Egyptian health professionals knew of type II FGM/C which is usually performed in Egypt [26].

In a study in North East London, $50 \%$ of senior doctors and only $7 \%$ of junior doctors had formal training in FGM/C; midwives were more confident in diagnosing FGM/C than doctors and $75 \%$ of medical students were aware of FGM/C complications [31]. However, in an earlier study of midwives and doctors who attend births, also in London, only $4 \%$ could correctly identify the different types of FGM/C and knowledge about the correct procedures to de-infibulate women during labour was poor for $\sim 45 \%$ of the respondents [35].

Survey respondents correctly identified a number of short and long-term complications of FGM/C although some studies reported that respondents knew of no complications after FGM/C (Table 4). Almost all participants (92\%) in the study in Birmingham, UK, correctly identified most long-term complications of FGM/C except for HIV/hepatitis and pelvic infection [30]. Only two studies asked about knowledge of psychological or psychosocial complications after FGM/C [30, 31].

Eleven per cent of Belgian doctors aged less than 40 years had been taught about FGM/C but only $1 \%$ knew of guidelines or information about FGM/C in their hospital [34]. Education on FGM/C is not regularly included in undergraduate education in Switzerland [37]. Few Swedish paediatricians knew about FGM/C and the motives behind FGM/C [36], and Norwegian health professionals felt that they had inadequate knowledge and skills about FGM/C and they called for specific training in how to speak with women and families about FGM/C and which words to use when raising the issue (Table 4).

In a survey of obstetricians and other health professionals working in a large UK clinic, $26 \%$ believed they had adequate training in FGM/C, $41 \%$ had been trained in de-infibulation, $31 \%$ knew that the hospital regularly screened for FGM/C and that the hospital had an obstetrician and a midwife that specialised in FGM/C [30]. Among paediatricians surveyed in Spain, $42.3 \%$ were aware of protocols and guidelines about FGM/C [33]. In the study from Belgium, $51 \%$ of gynaecologists surveyed, wanted relevant guidelines on FGM/C, 35 \% said they tried to prevent mothers who had FGM/C from allowing FGM/C to be performed in their female children, but $65 \%$ said they would not do any prevention [34].

3. Do health professionals have adequate knowledge about laws related to FGM/C?

In a recent study of members $(N=607)$ of the Royal College of Obstetricians and Gynaecologists in the UK, $94 \%$ understood that FGM/C is always illegal in the UK but $21 \%$ were unaware of the FGM/C Act, (Table 4) [30]. The majority ( $84 \%)$ of respondents said they would speak with a child protection officer if they suspected a child was at risk of FGM/C [30]. In the London study by Zaidi et al. $40 \%$ of health professionals were familiar with the FGM/C Act [35]. Relph et al. reported that only $60 \%$ of the UK health professionals surveyed were aware of current UK FGM/C law [31]. In the Belgian survey of gynaecologists, $45.5 \%$ knew that FGM/C was illegal in Belgium, the majority (85.6\%) understood that FGM/C constituted violence against women, but only $60 \%$ felt that it violated human rights [34]. Over a half (56\%) of midwives surveyed in a USA study knew that FGM/C was against the law [32]. In the Italian study of health professionals working with asylum seekers from FGM/C prevalent countries, less than half knew about the law prohibiting FGM/C in Italy [29].

Only $25 \%$ of the Sudanese respondents [23] and $17 \%$ of Egyptian respondents [24] knew that FGM/C was illegal in their country (Table 4). Furthermore, $35 \%$ of Egyptian doctors responding to survey conducted by Refaat et. al. did not approve of the law banning FGM/C [26]. However, all participants surveyed in a Nigerian study knew that FGM/C was illegal in some states [24].

4. What are the attitudes and beliefs of health professionals towards the practice of FGM/C?

Beliefs about the reasons for performing FGM/C varied widely with some respondents from both high income countries and from African countries believing that $\mathrm{FGM} / \mathrm{C}$ was done for religious reasons (Table 5). Surveys from African countries also cited other reasons including cultural, social, medical economic and cosmetic, included "preservation of virginity", "curbing promiscuity", and "improving the appearance of genitalia," while those from high income countries only cited cultural/traditional reasons or religious reasons (Table 5). In four surveys, between $4 \%$ and $48 \%$ of health professionals indicated that they would agree for their own daughters to undergo FGM/C [21, 25, 27, 28].

A minority of health professionals practising in high income countries were not against FGM/C. Seven of 344 Belgian doctors felt that FGM/C deserved respect 
because of cultural and religious connotations [34]. A survey of labour ward health personnel in the UK, showed that $14 \%$ believed that a competent adult should be allowed to consent to FGM/C, $9 \%$ felt that the procedure could be "medicalized" to prevent complications, and $17 \%$ said they would support a woman's request for re-infibulation [31]. Health professionals from high income countries indicated that they would reluctantly support re-infibulation of women from countries where this is customary to protect the woman from being marginalised from her community [26, 31]. In the ANZ study most respondents believed that it is acceptable to oversew labia majora to prevent infection and fusion, and for patient comfort [20]. Between $15 \%$ and 91 $\%$ of Egyptian health professionals surveyed, supported FGM/C if performed by a doctor to minimise harm (Table 5) [25-27].

Health professionals believed that laws will only be effective with the implementation of better awareness and education for patients and the community about FGM/ C $[24,33]$.

\section{Discussion}

Our review confirms that the practice of FGM/C continues and remains prevalent in some African countries despite many having adopted laws against this practice. We found 10 studies confirming that health professionals working in high income countries such as Australia, New Zealand, United Kingdom, Italy, Sweden, Belgium, Spain and Switzerland care for women and girls with FGM/C [4-7, 10-12, 21-23]. Some have been approached to perform $\mathrm{FGM} / \mathrm{C}$ in babies or young children [20, 24, 34, 37]. Furthermore, health professionals in Australia and New Zealand, the UK, Belgium and Switzerland believed that it was likely that some of their patients with $\mathrm{FGM} / \mathrm{C}$ had the procedure done in these high income countries despite legislation making FGM/ $\mathrm{C}$ illegal. Some health professionals did not know about anti-FGM/C laws or were unsure what these laws covered and what their obligations were under the laws [11]. There have been few prosecutions for FGM/C in countries where such laws exist [38]. Laws are not a deterrent if communities perceive that the risk of detection is low and there are few prosecutions $[4,5,38]$. To prevent the practice of $\mathrm{FGM} / \mathrm{C}$, health professionals felt that laws were not enough and needed to go hand in hand with awareness campaigns and education for patients and communities, including the men in those communities [24]. This is supported by the recently published UK Multi-Agency Practice Guidelines on Female Genital Mutilation [5].

Our systematic review is limited by the quality of the published studies, many with small sample sizes and low response rates. Although attitudes to FGM/C may differ according to the gender of the health professionals surveyed, this could not be assessed in our review due to inadequate sample description, seven of the 18 studies failing to report the gender of respondents.

The level of knowledge about FGM/C among health professionals varied with most unable to recognise the 4 different types of $\mathrm{FGM} / \mathrm{C}$ described by the WHO. Few were able to identify countries where $\mathrm{FGM} / \mathrm{C}$ is prevalent and therefore did not know that women from these countries are at high risk of FGM/ C. Health professionals who regularly worked with women from high risk communities and where the health service was targeted to these communities had better knowledge of FGM/C. However, even in a clinic in the UK that sees many women with FGM/C, only $26 \%$ felt that they had adequate training about FGM/C [23].

Only two studies included in our review reported on psychological and psychosocial problems, either immediate or long-term, which are associated with FGM/C [27, 30]. This is consitent with findings from a study by Mulongo et al. and supports the need to raise awareness in health professionals about these under-recognised consequence of FGM/C and the need to provide counselling services to support women and girls affected by FGM/C and their families [8].

Most of the studies surveyed obstetricians, gynaecologists, nurses, midwives and other health professionals working with pregnant women. Only two surveys reported separate data for paediatricians $[6,7]$. Paediatricians have an important role in recognising children at risk, preventing FGM/C by counselling parents and communities, reporting children to authorities, and in treating children who have undergone FGM/C and are suffering complications $[5,6,19]$. Of the 18 studies included in this review, only 5 addressed prevention of FGM/C, mainly through counselling women who have FGM/C and have recently given birth, against FGM/C for their daughters $[4-6,10,11]$. This is appropriate as the strongest predictor of a child undergoing FGM/C is the mother having undergone FGM/C herself [5]. However, in a study of Belgian obstetricians and gynaecologists $65 \%$ said they would not undertake to counsel women to prevent FGM/C among their daughters [10]. This may be because they feel inadequately trained and resourced to advocate against FGM/C. In a large survey of Belgian midwives, which was not included in our systematic review as it was only recently published on-line, the majority lacked adequate access to education and guidelines about FGM/C to provide adequate care, and to counsel mothers against FGM/C for their new born daughters [39].

Health professionals need education and guidelines relevant to FGM/C provided both in basic medical training and in continuing medical education. They wanted 
more information about how to speak with families about this culturally sensitive issue, how to recognise children who might be at risk of FGM/C and how to treat women and girls who have undergone FGM/C. The RACP guidelines on FGM/C provide a short summary of recommendations for paediatricians who may be faced with $\mathrm{FGM} / \mathrm{C}$, however, there is no practical guidance of what to do and what to say when dealing with a child with FGM/C or at risk of FGM/C and her family, often within a complex medical and sociocultural context [40]. Health professionals also called for better education about anti-FGM laws and their obligations under these laws.

As FGM/C often occurs in the community, there is a need for community health workers, general practitioners, community nurses and community paediatricians to be educated about FGM/C and to be provided with clear guidelines about what actions they need to take to prevent FGM/C, including guidance about when and how to report children to child protection authorities. Health professionals must also be provided with appropriate structures within the healthcare system, including referral pathways and specialist services for women and girls with FGM/C, and girls who may be at risk of FGM/C. Such pathways, integrating community prevention with inter-agency, inter-sectoral collaboration including schools, health services and community groups, has been recommended and is being implemented in the UK $[5,19]$. Furthermore, healthcare systems, practitioner credentialing bodies and communities have an important role in education and prevention of the medicalization of FGM/C [41].

\section{Conclusion}

This is the first literature review of health professionals' knowledge, attitudes and practice related to FGM/C. Only 18 studies were identified between the years 2000 and 2014, suggesting that this topic is under-researched. The review highlighted the need for easily accessible educational resources and evidence-based guidelines to enable health professionals to provide culturally sensitive medical and psychological care for women and girls who have undergone FGM/C. Furthermore, health professionals, especially paediatricians and family doctors, need skills to recognise women and girls at risk of FGM/ $\mathrm{C}$; they need resources to enable them to counsel girls and their families and communities to prevent this harmful and illegal practice. Most of the research papers reported on obstetricians, gynaecologists and other health professionals dealing with pregnant women. As the immigrant communities in high income countries become larger and increasingly multicultural and ethnically diverse, health professionals are more likely to see women and girls with $\mathrm{FGM} / \mathrm{C}$ or at risk of $\mathrm{FGM} / \mathrm{C}$, in their clinical practice. Further research is needed to determine knowledge gaps and needs for education and resources among other groups of clinicians including paediatricians, general practitioners and community health workers.

\section{Abbreviations}

FGM/C: Female genital mutilation or cutting; PRISMA: Preferred reporting Items for systematic reviews and meta-analyses.

\section{Competing interests}

The authors have no competing interests.

\section{Authors' contributions}

$Y Z$ and EE initiated the study, wrote the funding application, set the aims and methodology, including the search strategy. YZ screened the search publications, analysed and interpreted the data, and drafted the manuscript. PS assisted with search strategy development, conducted the search, screened the abstracts and assisted with data extraction. AP screened the search publications, extracted the data and assisted in writing the results. All authors revised the manuscript, provided comments and agreed with the

final submitted version. All authors read and approved the final manuscript.

\section{Acknowledgements}

This study was supported by a grant from the Australian Government Department of Health and Ageing, Health System Capacity Development Fund, Female Genital Mutilation Support Targeted Round (ITA DoHA/285/ 1213).

\section{Author details}

${ }^{1}$ Australian Paediatric Surveillance Unit, The Children's Hospital at Westmead, Sydney, Australia. ${ }^{2}$ Discipline of Paediatrics and Child Health, Sydney Medical School, The University of Sydney, Sydney, Australia. ${ }^{3}$ Sydney Children's Hospitals Network (Westmead), Sydney, Australia.

Received: 14 July 2015 Accepted: 26 November 2015

Published online: 10 December 2015

\section{References}

1. WHO. Eliminating female genital mutilation: the imperative 2008. Available from: http://whqlibdoc.who.int/publications/2008/9789241596442_eng.pdf (Accessed May 2015)

2. UNCIEF. Female Genital Mutilation/Cutting: A statistical overview and exploration of the dynamics of change.: UNICEF; 2013. ISBN 978-92-8064703-7]. Available from: http://www.childinfo.org/files/FGCM_Lo_res.pdf. (Accessed May 2015)

3. WHO. Global Strategy to stop health-care providers from performing female genital mutilation UNAIDS, UNDP, UNFPA, UNICEF, UNHCR, UNIFEM, WHO, FIGO, ICN, IOM, WCPT, WMA, MWIA. 2010; WHO/RHR/10.9. Available from: http://www.who.int/reproductivehealth/publications/fgm/rhr_10_9/en/ (Accessed May 2015)

4. Matthews B. Female genital mutilation: Australian law, policy and practical challenges for doctors. Med J Aust. 2011;194(3):139-41.

5. Multi-Agency Practice Guidelines: Female Genital Mutilation. HM Government, 2014. Available from: https://www.gov.uk/government/ uploads/system/uploads/attachment_data/file/380125/

MultiAgencyPracticeGuidelinesNov14.pdf (Accessed February 2015)

6. Kids New to Canada. A guide for health professionals working with immigrant and refugee children and youth. http://www.kidsnewtocanada. $\mathrm{ca} /$ screening/fgm (Accessed February 2015)

7. Denholm N. Female genital mutilation in New Zealand: understanding and responding. A guide for health and child protection professionals. FGM Education Programme for the New Zealand Ministry of Health, 2011; ISBN 978-0-478-35933-6. Available from: http://fgm.co.nz/resources (Accessed May 2015)

8. Mulongo P, Martin CH, McAndrew S. J Reprod Infant Psychol. 2014;32(5):469-485

9. UNFPA United Nations Population Fund, Female genital mutilation (FGM) frequently asked questions. Updated June 2015, Available from: http://www. unfpa.org/resources/female-genital-mutilation-fgm-frequently-askedquestions\#banned_by_law http://www.unfpa.org/resources/female-genital- 
mutilation-fgm-frequently-asked-questions\#banned_by_law (Accessed September 2015)

10. Leye E, Sabbe A. Overview of legislation in the European union to address female genital mutilation: challenges and recommendations for the implementation of laws. United nations division for the advancement of women, united nations economic commission for Africa international centre for reproductive health, Ghent university, Belgium international centre for reproductive health, 2009, EGM/GPLHP/ 2009/EP.09 Available from: http://www.un.org/womenwatch/daw/egm/ vaw_legislation_2009/Expert\%20Paper\%20EGMGPLHP\%20_Els\%20Leye_. pdf (Accessed May 2015)

11. Equality now. Female genital mutilation in the US Factsheet. Available from http://www.equalitynow.org/sites/default/files/EN_FAQ_FGM_in_US.pdf (Accessed May 2015)

12. Australian Government, Attorney-General's Department. Review of Australia's Female Genital Mutilation legal framework. Final Report. March 2013 http://www.ag.gov.au/publications/documents/ reviewofaustraliasfemalegenitalmutilationlegalframework/ review\%20of\%20australias\%20female\%20genital\% 20mutilation\%20legal\%20framework.pdf (Accessed February 2015)

13. United Nations. The Universal charter of human rights. http://www.un.org/ en/documents/udhr/ (Accessed February 2015)

14. United Nations Women. Convention on the elimination of all forms of discrimination against women. http://www.un.org/womenwatch/daw/ cedaw/cedaw.htm (Accessed February 2015)

15. Unicef. Fact sheet: a summary of the rights under the Convention on the Rights of the Child. www.unicef.org/crc/files/Rights_overview.pdf (Accessed February 2015)

16. African Committee of Experts on the Rights and Welfare of the Child. African charter on health and welfare of the child. http://pages.au.int/ acerwc/documents/african-charter-rights-and-welfare-child-acrwc (Accessed February 2015)

17. Pearce AJ, Bewley S. Medicalization of female genital mutilation. Harm reduction or unethical. Obstet Gyneacol Reprod Med. 2013;24(1):29-30

18. Serour Gl. Medicalization of female genital mutilation/cutting. Afr J Urol. 2013;19:145-9.

19. Hodes D, Armitage A, Robinson K, Creighton SM. Female genital mutilation in children presenting to a London Safeguarding clinic: a case series. Arch Dis Child. 2015; online first http://dx.doi.org/10.1136/archdischild-2014307234 (Article in press)

20. Moeed SM, Grover SR. Female genital mutilation/cutting (FGM/C): survey of RANZCOG fellows, diplomates \& trainees and FGM/C prevention and education program workers in Australia and New Zealand. Aust N Z J Obstet Gynaecol. 2012;52(6):523-7.

21. Ashimi A, Aliyu L, Shittu M, Amole T. A multicentre study on knowledge and attitude of nurses in northern Nigeria concerning female genital. mutilation. Eur J Contracept Reprod Health Care. 2014;19(2):134-40.

22. Kaplan A, Forbes M, Bonhoure I, Utzet M, Martin M, Manneh M, et al. Female genital mutilation/cutting in The Gambia: long-term health consequences and complications during delivery and for the newborn. Int J Womens Health. 2013:5(1):323-31.

23. Ali AA. Knowledge and attitudes of female genital mutilation among midwives in Eastern Sudan. Reprod Health. 2012;9:23.

24. Dike El, Ojiyi EC, Chukwulebe AE, Egwuatu VF. Female genital mutilation: Awareness and attitude of nursing and midwifery students in Afikpo, Nigeria. Internet Journal of Gynecology and Obstetrics. 2012; 16(3)1-6. Available from: http://ispub.com/JJGO/16/14274 (Accessed February 2015)

25. Rasheed SM, Abd-Ellah AH, Yousef FM. Female genital mutilation in Upper Egypt in the new millennium. Int J Gynecol Obstet. 2011;114(1):47-50.

26. Refaat A. Medicalization of female genital cutting in Egypt. East Mediterr Health J. 2009;15(6):1379-88.

27. Mostafa SRA, El Zeiny NAM, Tayel SES, Moubarak El. What do medical students in Alexandria know about female genital mutilation? East Mediterr Health J. 2006;12 Suppl 2:S78-92.

28. Onuh SO, Igberase GO, Umeora JO, Okogbenin SA, Otoide VO, Gharoro EP. Female genital mutilation: knowledge, attitude and practice among nurses. J Natl Med Assoc. 2006;98(3):409-14.

29. Caroppo E, Almadori A, Giannuzzi V, Brogna P, Diodati A, Bria P. Health care for immigrant women in Italy: are we really ready? A survey on knowledge about female genital mutilation. Ann Ist Super Sanita. 2014;50(1):49-53.
30. Purchase TC, Lamoudi M, Colman S, Allen S, Latthe P, Jolly K. A survey on knowledge of female genital mutilation guidelines. Acta Obstet Gynecol Scand. 2013;92(7):858-61.

31. Relph S, Inamdar R, Singh H, Yoong W. Female genital mutilation/cutting: knowledge, attitude and training of health professionals in inner city London. Eur J Obstet Gynecol Reprod Biol. 2013;168(2):195-8.

32. Hess RF, Weinland J, Saalinger NM. Knowledge of female genital cutting and experience with women who are circumcised: a survey of nurse-midwives in the united states. J Midwifery Womens Health. 2010;55(1):46-54.

33. Kaplan-Marcusan A, Toran-Monserrat P, Moreno-Navarro J, Castany Fabregas MJ, Munoz-Ortiz L. Perception of primary health professionals about female genital mutilation: from healthcare to intercultural competence. BMC Health Serv Res. 2009;9:11.

34. Leye E, Ysebaert I, Deblonde J, Claeys P, Vermeulen G, Jacquemyn Y, et al. Female genital mutilation: knowledge, attitudes and practices of Flemish gynaecologists. Eur J Contracept Reprod Health Care. 2008;13(2):182-90.

35. Zaidi N, Khalil A, Roberts C, Browne M. Knowledge of female genital mutilation among healthcare professionals. J Obstet Gynaecol. 2007;27(2): $161-4$.

36. Tamaddon L, Johnsdotter S, Liljestrand J, Essen B. Swedish health care providers' experience and knowledge of female genital cutting. Health Care Women Int. 2006;27(8):709-22.

37. Jager F, Schulze $S$, Hohlfeld P. Female genital mutilation in Switzerland: a survey among gynaecologists. Swiss Med Wkly. 2002;132(19-20):259-64.

38. Ridley L. FGM trial: why has no-one ever been convicted in Britain, despite the practice being illegal for 30 years? Huffington post. 2015. Available from: http://www.huffingtonpost.co.uk/2015/02/04/fgm-police-lead-makchishty-convictions-charges-evidence-illegal_n_5747672.html (Accessed June 2015).

39. Cappon S, L'Ecluse C, Clays E, Tency I, Leye E. Female genital mutilation: knowledge, attitude and practices of Flemish midwives. Midwifery. 2015; online first $h t t p: / / d x . d o i . o r g / 10.1016 /$ j.midw.2014.11.012 (Article in press)

40. Royal Australasian College of Physicians, 2012. Female genital mutilation and cutting. available from: https://www.racp.edu.au/docs/default-source/ advocacy-library/female-genital-mutilation-cutting.pdf (Accessed January 2015)

41. Johansen REB, Diop NJ, Laverack G, Leye E. What works and what does not: a discussion of popular approaches for the abandonment of female genital mutilation. Obstet Gyneacol Int. 2013;Article ID 348248Available from: www. hindawi.com/journals/ogi/348248(Accessed February 2015)

\section{Submit your next manuscript to BioMed Central and we will help you at every step:}

- We accept pre-submission inquiries

- Our selector tool helps you to find the most relevant journal

- We provide round the clock customer support

- Convenient online submission

- Thorough peer review

- Inclusion in PubMed and all major indexing services

- Maximum visibility for your research

Submit your manuscript at www.biomedcentral.com/submit 